\title{
First data on the spiders (Aranei) from the northern Gydan Peninsula, Russia
}

\section{Первые сведения о пауках (Aranei) северного Гыдана, Россия}

\author{
Andrei V. Tanasevitch*, Marina A. Khrisanova** \\ А.В. Танасевич*, М.А. Хрисанова** \\ * Institute of Ecology and Evolution, Russian Academy of Sciences, Leninsky prospekt 33, Moscow 119071, Russia. E-mail: \\ tanasevitch@gmail.com \\ * Институт проблем экологии и эволюции РАН, Ленинский проспект 33, Москва 119071, Россия. \\ ** Volokolamsk Road, 6, Krasnogorsk143402 Russia. E-mail: hrisanova2003@mail.ru \\ ** Волоколамское шоссе, 6, Красногорск 143402 Россия.
}

KEY WORDS: Spiders, Arctic, arctic tundra, typical tundra, Gydan Peninsula, NW Siberia, distribution.

КЛЮЧЕВЫЕ СЛОВА: Пауки, Арктика, арктические тундры, типичные тундры, Гыданский п-ов, северо-западная Сибирь, распространение.

\begin{abstract}
Eight spider species are recorded from the arctic and typical tundras of the Gydan Peninsula, NW Siberia, Russia. These species represent the Arctic fauna and belong to two families: Linyphiidae (7 species) and Tetragnathidae (1 species). In a regional aspect, this fauna is mostly composed of Siberian and Siberian-Nearctic elements; in a zonal aspect, it is typical arctic and contains only one polyzonal species. Their distributions between the different types of landscape and vegetation communities, as well as their distribution patterns are given. All species are new to the araneofauna of the region.
\end{abstract}

РЕЗЮМЕ. Впервые приведены данные о пауках арктических и типичных тундр п-ова Гыдан. Список включает восемь видов из двух семейств: Linyphiidae (7 видов) and Tetragnathidae (1 вид). В региональном плане, аранеофауна представлена в основном сибирскими и сибирско-неарктическими элементами, в зональном, имеет типично арктический облик и включает лишь 1 полизональный вид. Приведено распределение видов по различным зонально-ландшафтным категориям растительных сообществ; для каждого вида указан тип ареала и его зональная составляющая. Все виды - новые для полуострова.

\section{Introduction}

The Gydan Peninsula, an area of 160000 sq. km, is situated in the North of the West Siberian Plain, projecting far out into the Kara Sea, Arctic Ocean, between the Yamal and Taimyr peninsulas. In the West, the Gydan is bordered on the Tazovskaya and Ob' gulfs, in the East on the Yenisei River Gulf. The peninsula is characterized by a highly indented coastline which forms several secondary, smaller peninsulas like Yavay, Mammoth, etc.
Until recently, the Gydan Peninsula remained a terra incognita in an araneological sense: not a single spider species was recorded from this are which exceeds that of the Yamal Peninsula (122 000 sq. km) or Chukot Peninsula (110 000 sq. km). Only few spiders had been known from two territories adjacent to the Gydan: the village of Tazovsky (a triangle on Map) and the Nikandrovskiye Islands (a star on Map). Tazovsky lies on the western bank of Taz River outside the Gydan territory. Eight spider species had been registered from this locality: Agyneta mollis (O.PickardCambridge, 1871), Bathyphantes eumenis (L. Koch, 1879), Diplocephalus subrostratus (O. Pickard-Cambridge, 1873), Gonatium rubellum (Blackwall, 1841), Hilaira nivalis Holm, 1937, Hypselistes jacksoni (O. Pickard-Cambridge, 1902), Macrargus multesimus (O. Pickard-Cambridge, 1875) and Tenuiphantes nigriventris (L. Koch, 1879) [Eskov, 1987, 1988; Poryadina, 1998]. The Nikandrovskiye Islands are situated in the delta of Yenisei River, also beyond the peninsula. Two species had been recorded from there: Bathyphantes humilis (L. Koch, 1879) and Leptorhoptrum robustum (Westring, 1851) [Holm, 1973].

Only very recently, in a paper on the spiders of West Siberia by Marusik \& Koponen [2015], a list of species from three localities allegedly from the Gydan Peninsula was given. However, in fact only one of those localities lies within the Gydan, i.e. the one those authors referred to as No 1, "Messo Faktoria". Eventually, this cordon is a checkpoint of the Messoyakhinsky Nature Reserve. This locality (a square on Map) lies within the subzone of southern shrub tundra and supports of 41 spiders, including several unidentified closer to species. Locality No 2 in Marusik \& Koponen [2015], the environs of Tazovsky, as mentioned above, lies outside the peninsula while locality No 3 (op. cit.), which is situated much farther south, 


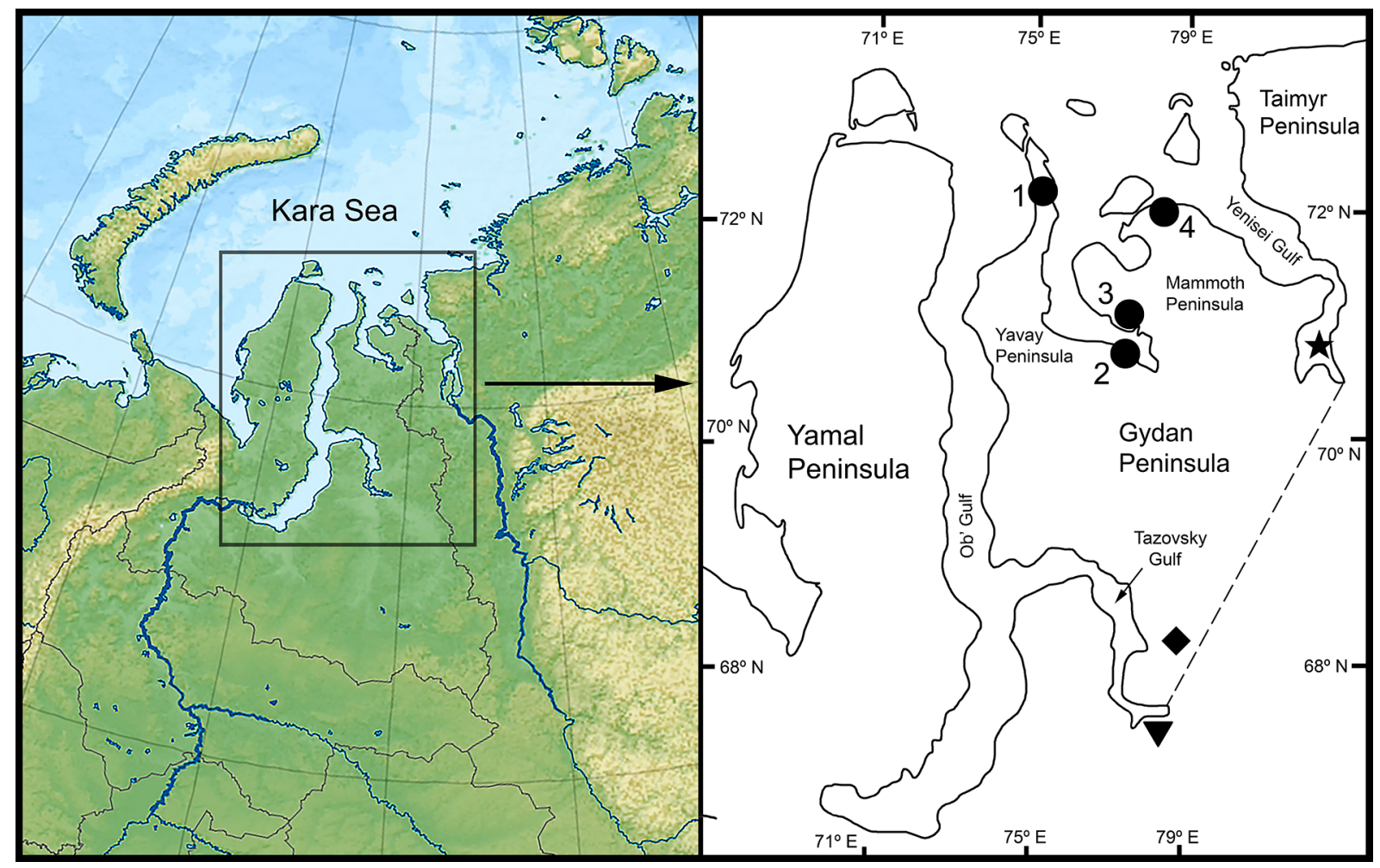

Map. Collecting localities in the Gydan Peninsula and adjacent territories. Circle — localities of the present study: 1 - L1 (a \& b), 2 — L2, 3 - L 3, 4 - L4 (a \& b), see above; star - Nikandrovskiye Islands [Holm, 1973]; triangle — Tazovsky Village [Eskov, 1987, 1988; Poryadina, 1998; Marusik \& Koponen, 2015]; square - Cordon "Messo" (= "Messo Faktoria" after Marusik \& Koponen, [2015]). Dotted line - southern border of the Gydan Peninsula.

Карта. Точки сбора материала на п-ове Гыдан и прилежащих территорий. Круг — сборы Хрисановой и Слодкевич (2013): 1 - L1 (a \& b), 2 - L2, 3 - L 3, 4 - L4 (a \& b), см. выше; звезда - Никандровские о-ва [Holm, 1973]; треугольник - пос. Тазовский [Eskov, 1987, 1988; Порядина, 1998; Marusik \& Koponen, 2015]; квадрат — кордон «Мессо» (= фактория «Мессо» по Marusik \& Koponen [2015]. Пунктирная линия — южная граница п-ова Гыдан.

is within the taiga belt and likewise has nothing to do with the peninsula.

During the Russian "Yamal-Arctica 2013" scientific expedition, a small but interesting material was taken from the arctic coast of Gydan Peninsula. Almost all of the territory of the peninsula belongs to the subzone of typical tundra of the tundra zone, except for a narrow southern part which is occupied of the subzone of southern shrub tundra; only the northernmost part of Yavay Peninsula lies within the subzone of arctic tundra [Chernov, Matveyeva, 1997]. This new material adds another eight species to the spider fauna of the Gydan Peninsula.

\section{Material, methods and localities}

All material was collected by M.A. Khrisanova \& V.Ya. Slodkevich using pitfall trapping. Four localities (see below) were covered during 28.VIII.-24.IX.2013. Altogether, about 140 adult spiders were taken from tundra landscapes. The animals belong to eight species in two families: Linyphiidae (7 species) and Tetragnathidae (1 species).

To characterize the distribution of the spiders between the different types of zonal landscape plant communities, the classification developed by Yu.I. Cher- nov [1978] was used. Based on it, there are three main zonal types of plant communities in the tundra: zonal ([ZC] in text and Table 1 below), intrazonal [IC] and azonal, the latter type being absent from this study; for more details, see Chernov [1978]; Tanasevitch \& Koponen [2007]; Tanasevitch \& Rybalov [2015].

Short descriptions of the localities are given below.

Locality 1 (L1). Yamal-Nenets Autonomous Region, Tazovsky Distr., Gydan Peninsula, northern part of Yavay Peninsula, $72.362402^{\circ} \mathrm{N} 75.091341^{\circ} \mathrm{E}$, 28.VIII.-1.IX.2013. Two different habitats were studied at this locality:

L1a: $72.360889^{\circ} \mathrm{N} 75.094278^{\circ} \mathrm{E}$, grass-lichen-moss tundra $[\mathbf{Z C}]$

L1b: $72.363667^{\circ} \mathrm{N} 75.083833^{\circ} \mathrm{E}$, wet sedge-moss tundra [IC].

Locality 2 (L2). Yamal-Nenets Autonomous Region, Tazovsky Distr., Gydan Peninsula, environs of Yuribei Trading Station, lower flow of Yuribei River, $71.037056^{\circ} \mathrm{N} 76.961944^{\circ} \mathrm{E}$, wet shrub tundra, in Salix bushes [IC], 3-5.IX.2013.

Locality 3 (L3). Yamal-Nenets Autonomous Region, Tazovsky Distr., Gydan Peninsula, southern coast of Mammoth Peninsula, $71.303306^{\circ} \mathrm{N} 77.525944^{\circ} \mathrm{E}$, grass-lichen-moss tundra [ZC], 7-10.IX.2013. 
Table 1. Species distributions between the tundra subzones and localities in the northern Gydan. Таблица 1. Распределение видов по подзонам и локалитетам на Северном Гыдане.

\begin{tabular}{|c|c|c|c|c|c|c|}
\hline \multirow{5}{*}{ Species } & \multicolumn{6}{|c|}{ Subzones of the tundra zone in the Gydan Peninsula } \\
\hline & \multicolumn{2}{|c|}{ Arctic tundra subzone } & \multicolumn{4}{|c|}{ Typical tundra subzone } \\
\hline & \multicolumn{6}{|c|}{ Collecting localities Точки сборов } \\
\hline & \multicolumn{2}{|c|}{ Yavay } & Yuribei & \multirow{2}{*}{$\begin{array}{c}\text { Mammoth } \\
\text { L3 (ZC) }\end{array}$} & \multicolumn{2}{|c|}{ Sosnovaya } \\
\hline & L1a (ZC) & L1b (IC) & L2 (IC) & & $\mathrm{L} 4 \mathrm{a}(\mathrm{ZC})$ & $\mathrm{L} 4 \mathrm{~b}(\mathrm{IC})$ \\
\hline \multicolumn{7}{|l|}{ Fam. Linyphiidae } \\
\hline Erigone psychrophila Thorell, 1872 & $10^{7}$ & $70^{7} \sigma^{7}, 2$ 우 & & & & \\
\hline Hilaira glacialis (Thorell, 1871) & $2 \sigma^{\top} \sigma^{\top}$ & & & $7 \bigcirc^{7} \sigma^{\top}, 2$ + & $\begin{array}{c}8 \sigma^{7} \sigma^{7} \\
1 \%\end{array}$ & $\begin{array}{c}5 \sigma^{\top} \sigma^{7} \\
5 \text { O }\end{array}$ \\
\hline H. incondita (L. Koch, 1879) & & $12 O^{7} \sigma^{7}, 22$ 우 & & & & $30^{7} 0^{7}$ \\
\hline H. nivalis Holm, 1937 & $\begin{array}{c}12 \sigma^{7} \sigma^{7} \\
5+9\end{array}$ & & $6 O^{\top} O^{\top}, 2$ + +9 & $1 \sigma^{7}$ & $\begin{array}{c}7 \sigma^{7} \sigma^{7} \\
2 \text { क्ष }\end{array}$ & $\begin{array}{l}70^{7} \sigma^{7} \\
8 \text { o }\end{array}$ \\
\hline H. proletaria (L. Koch, 1879) & $2 \sigma^{7} \sigma^{7}$ & $2 \sigma^{7} \sigma^{7}, 1$ ㅇ & $10^{7}$ & & & \\
\hline Masikia indistincta (Kulczyński, 1908) & & $1 \sigma^{\top}, 1$ 우 & & & & \\
\hline Mecynargus tundricola Eskov, 1988 & & & & 1 운 & & \\
\hline \multicolumn{7}{|l|}{ Fam. Tetragnathidae } \\
\hline Pachygnatha clercki Sundevall, 1823 & & $10^{7}, 1$ 우 & & & & \\
\hline Total samples & 22 & 50 & 9 & 11 & 18 & 28 \\
\hline
\end{tabular}

Abbreviations of localities see in Material, methods and localities.

Locality 4 (L4). Krasnoyarsk Area, Gydan Peninsula, Taimyr Dolgan-Nenets Distr., environs of Sosnovaya, a former trading station, $72.372041^{\circ} \mathrm{N} 78.617794^{\circ} \mathrm{E}$. Two different habitats were likewise studied at this locality:

L4a: plain watershed on high south bank of Yenisei River Gulf, $72.375417^{\circ} \mathrm{N} 78.614167^{\circ} \mathrm{E}$; dry sedge-moss tundra with Carex concolor, green mosses, Calamagrostis sp., Arctous sp., Dryas sp., Cassiope tetragone, Pyrola sp., etc. [ZC], 20-24.IX.2013;

L4b: depression on gentle slope of southern bank of Yenisei River Gulf near Mongocheyakha River mouth, $72.372041^{\circ} \mathrm{N} 78.617794^{\circ} \mathrm{E}$; wet sedge-moss tundra with Carex spp., Sphagnum spp., Pedicularis sp., etc. [IC], 20-24.IX.2013.

\section{Results and discussion}

Such a small number of species (eight) among about 140 adult specimens captured was due not only to the late collecting dates (August-September) and the use of only pitfall trapping, but also to the faunas of the northern belt of typical tundra and of the arctic tundra subzone in West Siberia being poor. Thus, despite a long history of research, the spider fauna of the Arctic tundra of Yamal Peninsula yields only 35 species [Tanasevitch \& Rybalov, 2015].

The distribution of spiders between the localities and different types of landscape vegetation communities (see above) is presented in Table 1. Of course such a small amount of material does not allow for a detailed analysis of distributions to be made, but such information may be useful in further research on topical preferences of species in different regions and sectors of the Arctic. Our material allows only to state that the number of species captured (7) in intrazonal habitats, and the catching efficiency of pitfall trapping 1.7 times, is higher than those in the zonal habitats (5).
In a regional aspect, the araneofauna of the northern territories of Gydan is mostly composed of Siberian and Siberian-Nearctic elements; there are only two species with Holarctic patterns (see Table 2). In a zonal aspect, the fauna is typical arctic and contains only one polyzonal species.

The araneofauna of the arctic and typical tundra subzones of Gydan Peninsula is very different from that of the subzone of southern shrub tundra. For the latter, 41 species of spiders have been recorded by Marusik \& Koponen [2015], all represented by typical boreal forms belonging to 10 families. All those species are absent from the fauna of northern Gydan. In turn, none of the inhabitants of arctic and typical tundras seems to occur in the southern tundra (except for Pachygnatha clercki Sundevall, 1823), indicating a high degree of zonal differentiation of the araneofauna of Gydan Peninsula.

ACKNOWLEDGEMENTS. We are sincerely grateful to V. Slodkevich (Moscow, Russia) for his help in collecting the field material, and to Sergei Golovatch (Moscow, Russia) for editing the English of an advanced draft. This study was supported by the Russian Foundation for Basic Research, Project \#15-04-05964.

Table 2. Distribution patterns of the spiders in the northern Gydan.

Таблица 2. Типы ареалов пауков Северного Гыдана.

\begin{tabular}{|c|c|c|}
\hline \multirow{2}{*}{ Species } & \multicolumn{2}{|c|}{ Distribution pattern } \\
\hline & Regional aspect & Zonal aspect \\
\hline Erigone psychrophila & Holarctic & arctic \\
\hline Hilaira glacialis & Siberian & arcto-boreo-montane \\
\hline H. incondita & Siberian-Nearctic & arcto-boreal \\
\hline H. nivalis & West Siberian & arctic \\
\hline H. proletaria & Siberian-West Nearctic & arcto-boreal \\
\hline Masikia indistincta & Siberian-Nearctic & arctic \\
\hline Mecynargus tundricola & Siberian & arcto-boreal \\
\hline Pachygnatha clercki & Holarctic & polyzonal \\
\hline
\end{tabular}




\section{References}

Chernov Yu.I., Matveyeva N.V. 1997. Arctic Ecosystems in Russia // Ecosystems of the World. 3. Polar and alpine tundra. Amsterdam etc.: Elsevier. P.361-507.

Eskov K.Yu. 1987. New data on spiders of the genus Hilaira (Aranei, Linyphiidae) in the fauna of the USSR // Zool. Zhurnal. Vol.65. No.7. P.1020-1031 [in Russian, with English summary].

Eskov K.Yu. 1988. The spider genera Savignya Blackwall, Diplocephalus Bertkau and Archaraeoncus Tanasevitch (Aranei, Linyphiidae) in the fauna of Siberia and the Soviet Far East // Folia Entomol. Hung. T.49. P.13-39.
Holm A. 1973. On the spiders collected during the Swedish expedition to Novaya Zemlya and Yenisey in 1875 and 1876 // Zool. Scripta. Vol.2. No.3. P.71-110.

Marusik Yu.M., Koponen S. 2015. New biogeographical records of spiders and harvestmen (Arachnida: Araneae \& Opiliones) from West Siberia, including an annotated list of species // Acta Entomologica Fennica. Vol.24. No.4. P.165-170.

Poryadina N.M. 1998. [Spiders (Aranei) of the subzone of southern tundra] // S.I. Pavlov (ed.). Problemy entomologii Evropeiskoy chasti Rossii i sopredel'nykh territoriy. Tezisy dokladov 1-go mezhdunarodnogo soveshchaniya (7-11 iyunya 1993, Bakhilova Polyana). Samara: izdatel'stvo "Samarskiy universitet". P.144 [in Russian].

Responsible editor K.G. Mikhailov 